\title{
MENINGKATKAN KEMAMPUAN MENULIS PENGUMUMAN DENGAN MENGGUNAKAN MODEL NUMBERED HEADS TOGETHER PADA SISWA KELAS VII A MTS MIMBATUL AKHLAQ KECAMATAN
}

PENGABUAN TAHUN AJARAN 2016/2017

\section{Rosdiana, Abdoel Gafar}

\begin{abstract}
This research is conducted due to the first observation towards students class VII A learning outcome in MTs Mimbatul Akhlaq Kecamatan Pengabuan. There is a problem in students class VII A writing ability in MTs Mimbatul Akhlaq Kecamatan Pengabuan. Students have lack of motivation in writing an announcement. This situation is supported by their mark in writing. It is on the scale of not complete. This research is classroom action research with 2 cycles planning, acting, observing, and reflecting. The subject of the research is teacher and students of class VII A MTs Mimbatul Akhlaq Kecamatan Pengabuan. There are 28 students.

This research is aimed at describing students ability in writing an announcement through model Numbered Heads Together at class VII A MTs Mimbatul Akhlaq Kecamatan Pengabuan Academic Year 2016/2017. The researcher chooses this research because the students writing ability is still low and need to be fixed. This research is expected to give a motivation so that students will have a skill in writing an announcement. The learning model which is used in this research is model Numbered Heads Together, with LKS then students make discussion which is related with that announcement. The method is descriptive quantitative. The result of the research shows that in cycle I the mean is 73,75 and in cycle II there is an improvement with the mean 75,71. Based on the conclusion of the analysis, it is good for a teacher to give writing exercise on how to make an announcement and the school should give an opportunity and chance to the teacher to do classroom action research.
\end{abstract}

Kata Kunci: ability, writing an announcement, model numbered heads together

PENDAHULUAN

Pembelajaran keterampilan menulis merupakan aktivitas untuk memahami segala sesuatu informasi baik itu fakta, data maupun peristiwa termasuk pendapat dan pandangan terhadap fakta, juga peristiwa agar khalayak pembaca memperoleh pengetahuan dan pemahaman baru tentang berbagai hal yang dapat terjadi dimuka bumi ini. Di sekolah pembelajaran menulis perlu difokuskan pada aspek kemampuan memahami isi tulisan, oleh sebab itu,

Meningkatkan Kemampuan Menulis Pengumuman Dengan Menggunakan Model Numbered Heads

Together Pada Siswa Kelas Vii A Mts Mimbatul Akhlaq Kecamatan Pengabuan Tahun Ajaran 
siswa perlu dilatih intensif untuk memahami sebuah teks tulisan. Maka hal ini siswa bukan menghafal isi tulisan tersebut, melainkan memahami isi dari tulisan. Dalam hal ini peran guru sangat besar pengaruhnya terhadap kemampuan siswa dalam memahami isi tulisan tersebut. Guru bahasa Indonesia sebaiknya mengajarkan siswa tentang strategi dan teknik menulis yang benar dan baik sehingga siswa mampu memahami isi tulisan dengan baik pula.

Berdasarkan observasi peneliti laksanakan di lapangan, terutama siswa di sekolah MTs Mimbatul Akhlaq khususnya kelas VII A ternyata masih banyak yang belum paham tentang cara menulis. Hal ini diketahui di dalam mata pelajaran bahasa Indonesia yang terdapat materi menulis pengumuman masih banyak terdapat kesalahan yakni dari cara menulis kalimat demi kalimat yang sering di campur dengan bahasa daerah, pemakain huruf yang tidak sesuai pada tempatnya, susunan kalimatnya yang tidak berkesinambungan, bahkan masih ada siswa yang belum pahan cara menulis pengumuman, itu semua karena kurangnya motivasi belajar siswa di kelas VII A yang saat ini menjadi sesuatu hal yang menarik perhatian peneliti ingin menindaklanjuti apa yang menyebabkan mereka kesulitan dalam menulis pengumuman.

Dari data yang diperoleh tersebut maka perlu peneliti laksanakan kegiatan pembelajaran yang inovatif untuk meningkatkan prestasi belajar siswa pada mata pelajaran bahasa Indonesia. Berdasarkan uraian masalah di atas, maka pemecahan masalah tersebut peneliti mencobah alternatif tindakan untuk meningkatkan prestasi belajar bahasa Indonesia pada aspek menulis pada siswa kelas VII A MTs Mimbatul Akhlaq Kecamatan Pengabuan, yakni dengan menggunakan model pembelajaran Numbered Heads Together yang nantinya diharapkan siswa dapat terlibat secara aktif dalam pembelajaran, meningkatkan keterampilan guru, dan keterampilan menulis pengumuman pada siswa. Bukan hanya itu saja dengan menggunakan model Numbered Heads Together (NHT) ini nantinya 
diharapakan dapatnya tercapai target yang diinginkan yaitu tercapainya kriteria ketuntasan minimal (KKM), namun jika belum tuntas maka peneliti akan menindaklanjuti dengan melakukan siklus tiga.

\section{METODOLOGI}

Jenis penelitian yang digunakan adalah Penelitian Tindakan Kelas (PTK) yang pertama kali dikenalkan oleh ahli psikologi sosial Amerika yang bernama Kurt Lewin pada tahun 1946. Penelitian Tindakan Kelas adalah penelitian yang mengacu kepada tindakan yang dapat dilakukan guru secara langsung dalam usaha memperbaikai proses belajar mengajar terutama dalam proses menulis. Penelitian ini bertujuan mendeskripsikan masalah-masalah dan temuan-temuan yang ada dalam penelitian. Penelitian ini mengkaji gejala-gejala alamiah di dalam pengajaran bahasa Indonesia khususnya dalam penerapan kooferatif melalui model NHT terhadap kemampuan menulis pengumuman siswa. Kemudia dilihat peristiwa yang terjadi dalam proses interaksi siswa, siswa dengan guru, dan kejadian lainnya.

Zainal, Eko dkk (2011:3) menjelaskan bahwa "Penelitian tindakan kelas adalah penelitian yang dilakukan oleh guru di kelasnya sendiri melalui refleksi diri dengan tujuan untuk memperbaiki kinerjanya sehingga hasil belajar siswa meningkat". Jadi PTK merupakan suatu penelitian yang mengangkat masalah-masalah aktual yang sering dihadapi guru di lapangan maka dari itu dengan

Adapun pendapat dari teori yang sedikit berbeda dengan para ahli yang lain yaitu pendapat dari Carr dan Kemmis (McNiff,

mendevinisikan PTK sebagai berikut:

"Action research is a from of selfrefective enquiry undertaken by participants (teacher, student or principals, for exsample) in social (including educational) situation in order to imfrove the rationality and justice of their own social or educational practices, their understanding of these practices, and the situation (and institution) in which the practices are carried out."

Meningkatkan Kemampuan Menulis Pengumuman Dengan Menggunakan Model Numbered Heads

Together Pada Siswa Kelas Vii A Mts Mimbatul Akhlaq Kecamatan Pengabuan Tahun Ajaran 
Berdasarkan pengertian di atas, dapat digarisbawahi beberapa poin penting tentang PTK, yakni:

1) PTK adalah suatu bentuk inquiry atau penyelidikan yang dilakukan melalui refleksi diri.

2) PTK dilakukan oleh peserta yang terlibat dalam situasi yang diteliti, seperti guru, peserta didik, atau kepala sekolah.

3) PTK dilakukan dalam situasi sosial, termasuk situasi pendidikan.

4) Tujuan PTK adalah untuk memperbaiki dasar pemikiran dan kepantasan dari praktik-praktik belajar-mengajar, memperbaiki pemahaman dari praktik belajarmengajar, serta memperbaiki situasi atau lembaga tempat praktik tersebut dilakukan.

Penelitian ini dilaksanakan di MTs Mimbatul Akhlaq Kecamatan Pengabuan Kabupaten Tanjung Jabung Barat pada tahun 2016/2017. Penelitian Tindaka Kelas (PTK) dilakukan pada siswa kelas VII A yang dilaksanakan pada bulan Juni 2017, kegiatan penelitian ini dilakukan dalam dua siklus yaitu siklus I dan siklus II.

\section{HASIL PENELITIAN DAN PEMBAHASAN}

\section{Hasil Penelitian}

Kondisi setelah dilaksanakannya siklus I ada 13 siswa yang nilai hasil belajarnya belum mencapai KKM, maka dilakukan untuk penelitian selanjutnya pada siklus ke II dan hasilnya 4 siswa yang belum mencapai KKM dan sisanya 24 siswa telah mencapai KKM. Maka dapat dikatakan telah berhasil di siklus ke II karena telah mencapai keberhasilan 85 $\%$ siswanya mencapai KKM. Sehingga tidak perlu lagi dilanjutkan ke siklus III.

Daftar nilai setelah siklus penelitian tindakan kelas mata pelajaran bahasa Indonesia MTs Mimbatul Akhlaq Kecamatan Pengabuan tahun pelajaran 2016/2017

Meningkatkan Kemampuan Menulis Pengumuman Dengan Menggunakan Model Numbered Heads Together Pada Siswa Kelas Vii A Mts Mimbatul Akhlaq Kecamatan Pengabuan Tahun Ajaran 
Kelas : VII (Tujuh) A

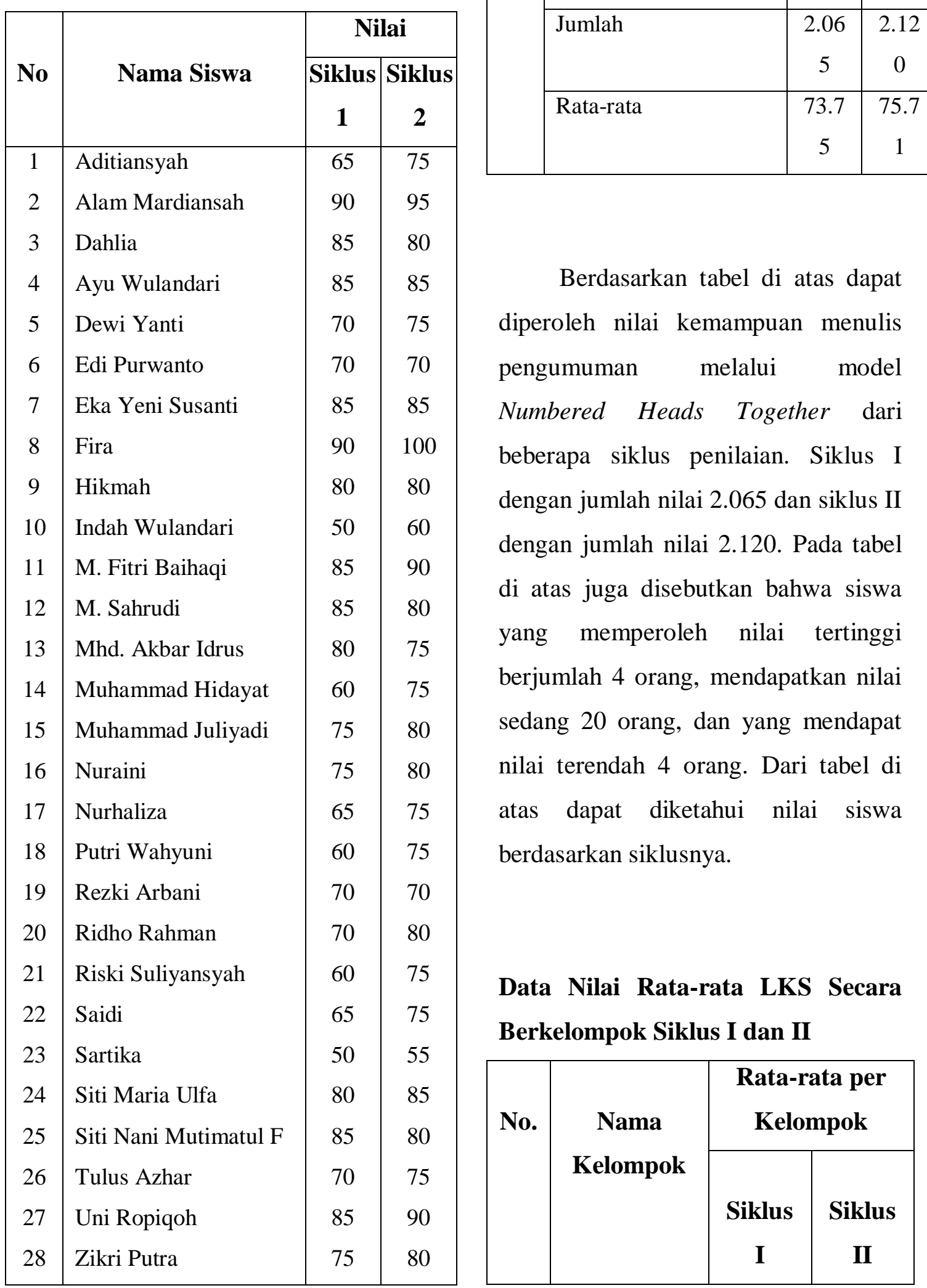

Meningkatkan Kemampuan Menulis Pengumuman Dengan Menggunakan Model Numbered Heads Together Pada Siswa Kelas Vii A Mts Mimbatul Akhlaq Kecamatan Pengabuan Tahun Ajaran 


\begin{tabular}{|c|c|c|c|}
\hline 1. & Kelompok I & 79 & 82 \\
\hline 2. & Kelompok II & 75 & 79 \\
\hline 3. & $\begin{array}{c}\text { Kelompok } \\
\text { III }\end{array}$ & 77 & 80 \\
\hline 4. & $\begin{array}{c}\text { Kelompok } \\
\text { IV }\end{array}$ & 68 & 76 \\
\hline 5. & Kelompok V & 68 & 74 \\
\hline 6. & $\begin{array}{c}\text { Kelompok } \\
\text { VI }\end{array}$ & 76 & 81 \\
\hline
\end{tabular}

\section{Kecamatan Pengabuan Tahun \\ Pelajaran 2016/2017}

\begin{tabular}{|c|c|c|c|}
\hline $\mathbf{N}$ & Nama Siswa & $\begin{array}{l}\mathbf{N i} \\
\text { lai }\end{array}$ & $\begin{array}{c}\text { Kate- } \\
\text { gori }\end{array}$ \\
\hline 1 & Aditiansyah & 75 & Tuntas \\
\hline 2 & Alam Mardiansah & 95 & Tuntas \\
\hline 3 & Dahlia & 80 & Tuntas \\
\hline 4 & Ayu Wulandari & 85 & Tuntas \\
\hline 5 & Dewi Yanti & 75 & Tuntas \\
\hline 6 & Edi Purwanto & 70 & Tidak tuntas \\
\hline 7 & Eka Yeni Susanti & 85 & Tuntas \\
\hline 8 & Fira & 100 & Tuntas \\
\hline 9 & Hikmah & 80 & Tuntas \\
\hline 10 & Indah Wulandari & 60 & Tidak tuntas \\
\hline 11 & M. Fitri Baihaqi & 90 & Tuntas \\
\hline 12 & M. Sahrudi & 80 & Tuntas \\
\hline 13 & Mhd. Akbar Idrus & 75 & Tuntas \\
\hline 14 & Muhammad Hidayat & 75 & Tuntas \\
\hline 15 & Muhammad Juliyadi & 80 & Tuntas \\
\hline 16 & Nuraini & 80 & Tuntas \\
\hline 17 & Nurhaliza & 75 & Tuntas \\
\hline 18 & Putri Wahyuni & 75 & Tuntas \\
\hline 19 & Rezki Arbani & 70 & Tidak tuntas \\
\hline 20 & Ridho Rahman & 80 & Tuntas \\
\hline 21 & Riski Suliyansyah & 75 & Tuntas \\
\hline 22 & Saidi & 75 & Tuntas \\
\hline 23 & Sartika & 55 & Tidak tuntas \\
\hline 24 & Siti Maria Ulfa & 85 & Tuntas \\
\hline 25 & Siti Nani Mutimatul & 80 & Tuntas \\
\hline 26 & Tulus Azhar & 75 & Tuntas \\
\hline 27 & Uni Ropiqoh & 90 & Tuntas \\
\hline 28 & Zikri Putra & 80 & Tuntas \\
\hline & Jumlah & 2.120 & \\
\hline
\end{tabular}

Meningkatkan Kemampuan Menulis Pengumuman Dengan Menggunakan Model Numbered Heads

Together Pada Siswa Kelas Vii A Mts Mimbatul Akhlaq Kecamatan Pengabuan Tahun Ajaran 


\begin{tabular}{|l|l|l|}
\hline Rata-rata & 75.71 & \\
\hline
\end{tabular}

Berdasarkan tabel di atas diperoleh data berdasarkan skala penilaian kemampuan menulis pengumuman melalui model $N H T$. Berdasarkan kategori penilaian, diperoleh dari jumlah 28 siswa dengan cara membagi jumlah nilai dengan jumlah seluruh siswa. Maka, diperoleh hasil rata-rata 75,71 dengan predikat baik. Data tersebut berdasarkan kemampuan yang dimiliki siswa.

\section{Pembahasan}

Berdasarkan hasil pembelajaran kemampuan menulis pengumuman melalui model Numbered Heads Together, pada siswa kelas VII A MTs Mimbatul Akhlaq Kecamatan Pengabuan Tahun Pelajaran 2016/2017. Diperoleh nilai kemampuan menulis pengumuman melalui model Numbered Heads Together berdasarkan dari sisklus I jumlah keseluruhan nilai siswa adalah 2065 dengan rata-rata 73, 75 yang berarti belum mencapai KKM, kemudian dilanjutkan lagi dengan siklus II dan memperoleh nilai keseluruhan dengan jumlah 2120 dengan rata-rata 75,71 yang berarti telah mencapai KKM.

Selain itu dari nilai individu siswa ada juga nilai perkelompok yang telah diperoleh siswa. Dapat dilihat dari siklus I masih ada 2 kelompok yang memperoleh nilai rendah atau belum mencapai KKM, namun setelah diadakan siklus II semua kelompok mencapai nilai KKM yang diinginkan. Dengan demikian dapat dikatakan bahwa pada siklus II semua anak berhasil dalam kelompok diskusi bahkan ada kelompok yang mencapai nilai tertinggi. Setelah terlaksananya siklus I dan siklus II dan pada siklus II sudah mencapai $85 \%$ bahwa dinyatakan siswa telah berhasil dalam proses pembelajaran menulis pengumuman melalui model Numbered Heads Together

\section{KESIMPULAN DAN SARAN}

\section{Kesimpulan}

Berdasarkan hasil penelitian yang telah dilakukan peneliti tentang kemampuan menulis pengumuman melalui model Numbered Heads 
Together pada siswa kelas VII A MTs Mimbatul Akhlaq Kecamatan Pengabuan tahun pelajaran 2016/2017, dapat ditarik kesimpulan bahwa kemampuan menulis pengumuman berjalan dengan baik. Predikat ini ditentukan dari nilai rata-rata yang diperoleh siswa 75,71 dengan predikat baik yang dihasilkan berdasarkan keefektifan bahasa, (535), penulisan kalimat (510), pilihan kata atau diksi (485), dan kejelasan isi (605).

Berdasarkan nilai akhir menulis pengumuman melalui model Numbered Heads Together, seluruh nilai siswa yang berjumlah 28 orang dijumlahkan dan mendapatkan nilai keseluruhan 2120. Berdasarkan skala penilaian kemampuan menulis pengumuman melalui meodel Numbered Heads Together, diperoleh dari jumlah seluruh siswa 28 orang dengan cara membagi jumlah nilai dengan jumlah seluruh siswa. Maka, diperoleh nilai rata-rata 75, 71 dengan predikat baik.

\section{Saran}

Sebagai penutup dari hasil penelitian ini ada beberapa saran yang perlu penulis sampaikan sebagi berikut:

1. Guru sebaiknya dapat menggunakan berbagai bahan ajar yang sesuai dengan materi pembelajaran dan mengembangkan metode pembelajaran yang beranekaragam. 50

2. Sekolah hendaknya dapat memberikan kesempatan dan dukungan kepada guru untuk menggunakan metode pembelajaran yang beragam.

3. Bagi peneliti hendaknya dapat menjadi ilmu pengetahuan baru tentang kemampuan menulis pengumuman melalui model Numbered Heads Together.

DAFTAR PUSTAKA

Amus A Sogalery, T 2011. "Peningkatan Keterampilan Menulis Paragraf Melalui Model Numbered Heads Together”. Skripsi. Kota Malang: Program Sarjana Universitas Negeri Malang.

Aqib Zainal, dkk. 2008. Penelitian Tindakan Kelas. Margahayu 
Permai, Bandung: CV Yrama Widya.

Dalman. 2014. Keterampilan Menulis. Jakarta: Rajawali Pers.

Dimiyati dan Mudjiono. Belajar dan Pembelajaran. 2013. Jakarta: Rineka Cipta

Dita Fajriah, T 2015. “Keterampilan Menulis Pengumuman Melalui Model Numbered Heads Together Dengan Media Surat Kabar”. Skripsi. Semarang: Program Sarjana UNNES.

http://repository.unpas.ac.id. (jurnal online) langkah-langkah pengumuman diakses pada tanggal 10 Juni 2017.

Isnawati Esti. 2012. Metode Penelitian

Pendidikan Bahasa dan sastra. Yogyakarta: Penerbit Ombak.

Kurniasih Imas dan Sani Berlin. 2016.

Ragam Pengembangan Model

Pembelajaran: Kata Pena.

Ningsih, sri. 2008. Bahasa Indonesia. Surabaya. Pusat Perbukuan.
Sabarti Arkhadiah, Maidar, dan Sakura Ridwan. 2003. Pembinaan Kemampuan Menulis Bahasa Indonesia. Jakarta. Erlangga

Slameto. 2001. Evaluasi Pendidikan. Jakarta: PT Bumi Aksara.

Suparno dan Mohamad Yunus. 2009.

Keterampilan Dasar Menulis. Kementrian Pendidikan Nasional: Universitas Terbuka.

Suparno, dkk. 2008. Bahasa dan Sastra Indonesia 1. Jakarta. PT Bumi Aksara.

Suprijono Agus. 2013. Cooperatif Learning. Yogyakarta: Pustaka Belajar.

Suyadi. 2011. Panduan Penelitian Tindakan Kelas. Jogjakarta. DIVA Press.

Pamungkas. 1972. Pedoman Umum Ejaan Yang Disempurnakan. Surabaya: Apollo Lestari.

Pardjimin. 2005. Bahasa dan Sastra Indonesia. Perpustakaan Nasional. Tim Prima Pena. Kamus Besar Bahasa Indonesia. Gitamedia Press. 
Jurnal AKSARA : Jurnal IImiah Pendidikan Bahasa dan Sastra Indonesia Vol.1 No.1 September 2017

Wahono, Mafrukhi, dkk. 2013. Mahir Yoni Acep, dkk. Menyusun Penelitian

Berbahasa Indonesia Untuk Tindakan Kelas. 2010. Yogyakarta.

SMP/MTs Kelas VII. Jakarta:

Penerbit Erlangga.

Meningkatkan Kemampuan Menulis Pengumuman Dengan Menggunakan Model Numbered Heads Together Pada Siswa Kelas Vii A Mts Mimbatul Akhlaq Kecamatan Pengabuan Tahun Ajaran $2016 / 2017$ 